\title{
ANALISIS VISKOSITAS, MASSA JENIS, DAN KEKERUHAN MINYAK GORENG CURAH BEKAS PAKAI
}

\author{
Fita Widiyatun ${ }^{1}$, Noni Selvia ${ }^{2}$, Nurfidah Dwitiyanti ${ }^{3}$ \\ Informatika, Universitas Indraprasta PGRI Jakarta \\ fita.wdy@gmail.com
}

Submitted February 7, 2019; Revised June 23, 2019; Accepted July 28, 2019

\begin{abstract}
Abstrak
Minyak goreng merupakan salah satu bahan yang sering digunakan untuk memasak. Hal yang umum terjadi dimasyatakat adalah penggunaan minyak goreng untuk beberapa kali proses penggorengan. Nilai kualitas dari minyak goreng yang telah digunakan untuk menggoreng, maupun sebelum digunakan tentunya berbeda. Terlebih lagi untuk minyak goreng curah. Berdasarkan hal tersebut, maka perlu dilakukan analisis untuk mengetahui viskositas, massa jenis dan kekeruhan minyak goreng habis pakai. Minyak goreng curah yang akan diteliti, digunakan terlebih dahulu untuk menggoreng tempe dan ikan teri sebanyak 1 kali, 2 kali, dan 3 kali penggorengan. Minyak tersebut kemudian dianalisis dengan mengukur kekentalan, massa jenis, dan kekeruhan. Hasil yang diperoleh dari penelitian diketahui bahwa nilai pengukuran secara kuantitas pada parameter kekeruhan dan viskositas mempunyai nilai yang berbeda. Sedangkan pada pengukuran massa jenis, memiliki nilai yang hampir sama, hanya berbeda pada minyak goreng 1 kali penggorengan.
\end{abstract}

Kata Kunci : minyak curah, viskositas, massa jenis, kekeruhan

\begin{abstract}
Cooking oil is one of the ingredients that is used for cooking. In our community, it is usually used for cooking for several frying processes. In fact, the quality of cooking oil that has been used and that has not been used for frying is totally different, especially for bulk cooking oil. Based on this fact, it is necessary to do an analysis to know the viscosity, density and turbidity of the consumable cooking oil. The bulk cooking oil to be researched is first used to fry tempehs and anchovies for one, two, and 3 times. The oil is then analyzed by measuring its viscosity, density, and turbidity. The result of the research shows that the quantitative measurement within turbidity and viscosity parameters has different values. As for measurement of density, it has almost the same value, with little difference in cooking oil used for frying once.
\end{abstract}

Keywords : Bulk cooking oil, viscosity, density, turbidity

\section{PENDAHULUAN}

Di Indonesia, banyak sekali ditemukan makanan yang diolah dengan cara digoreng. Besarnya penggunaan minyak goreng, disebutkan bahwa konsumsi minyak goreng di Indonesia rata-rata sebesar 20 gram/hari [4]. Minyak goreng merupakan salah satu bahan yang sangat diperlukan untuk membuat makanan. Baik untuk kegiatan memasak rumah tangga, maupun untuk berjualan seperti berjualan gorengan di pinggir jalan. Minyak goreng, dalam pemakaiannya sangat rentan sekali untuk digunakan secara berulang kali. Penggunaan minyak goreng yang dipakai berkali-kali dalam proses penggorengan, akan sangat berpengaruh terhadap kualitas dari minyak goreng maupun bahan yang digoreng tersebut. Proses penggorengan menggunakan minyak goreng akan merusak stabilitas dan isi dari bahan-bahan yang digoreng [1][2].

Minyak goreng curah, pada umumnya sering ditemukan di pasar-pasar tradisional dijual dengan tanpa kemasan. Kurang lebih sebesar $70 \%$ minyak kelapa sawit dijual sebagai minyak curah [4]. Hal tersebut mengakibatkan minyak tersebut terpapar oksigen sebelum digunakan untuk 
menggoreng [1]. Banyaknya dan mudahnya minyak goreng curah ditemukan di pasar-pasar tradisional, serta besarnya konsumsi masyarakat akan minyak goreng, maka perlu diadakan penelitian tentang kualitas minyak goreng curah, terutama kualitas setelah minyak tersebut digunakan untuk penggorengan.

Pada penelitian ini, telah dilakukan penelitian tentang minyak goreng curah yang digunakan untuk menggoreng ikan teri dan tempe. Kedua bahan tersebut dipilih karena baik tempe ataupun ikan teri sering dikonsumsi oleh masyarakat. Parameter yang diukur adalah nilai viskositas (kekentalan), densitas (massa jenis), serta tingkat kekeruhan dari minyak goreng curah bekas pakai tersebut. Viskositas merupakan gesekan yang terjadi pada internal fluida, sedangkan massa jenis merupakan massa tiap satuan volumenya. Dengan mengetahui ketiga parameter tersebut di atas, diharapkan dapat mengetahui keadaan kualitas dari minyak goreng curah habis pakai.

\section{METODE PENELITIAN}

Penelitian dilakukan pada bulan September - Desember 2018. Pembuatan sampel dilakukan di Bekasi, sedangkan analisis sampel terhadap parameter viskositas, massa jenis, maupun kekeruhan dilakukan di Universitas Indonesia. Tahapan- tahapan yang dilakukan dalam penelitian seperti terlihat pada Gambar di bawah ini :

\section{Persiapan sampel}

Alat dan bahan yang digunakan dalam penelitian ini diantaranya minyak goreng curah yang diperoleh dari pasar tradisional di daerah Bekasi, air, wadah/toples, tempe, ikan teri, bawang putih, garam, botol vial $100 \mathrm{ml}$, gelas ukur, dll.

Tempe diiris sesuai selera kemudian dimasukkan ke dalam bumbu yang telah disediakan. Tempe tersebut kemudian didiamkan kurang lebih sekitar 10 menit atau sampai bumbu meresap ke dalam

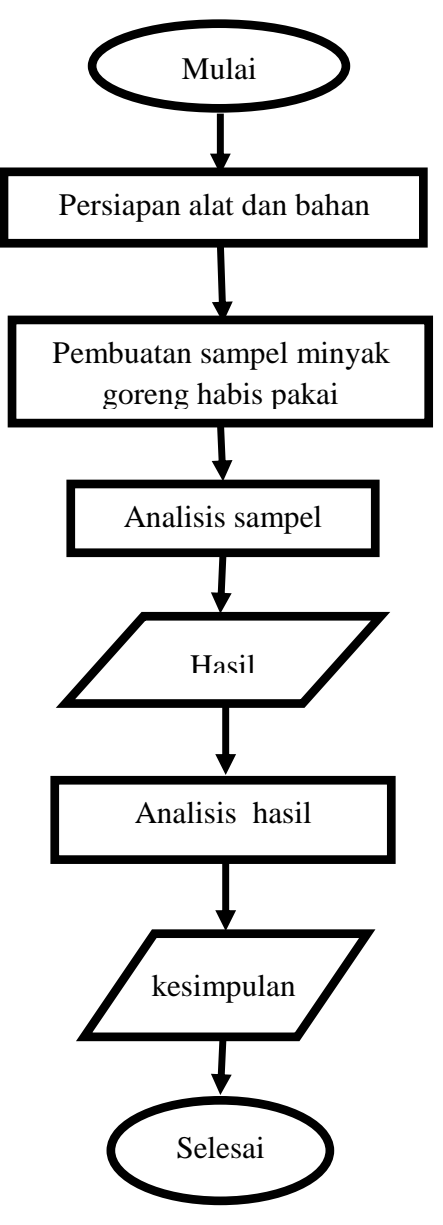

Sumber : dokumen pribadi

\section{Gambar 1. Diagram alir penelitian.}

tempe. Setelah itu, tempe kemudian ditiriskan.

Kurang lebih sekitar 0,5 liter minyak goreng curah disiapkan dan dipanaskan di dalam wajan. Setelah panas, masukkan tempe yang telah ditiriskan ke dalam wajan dan digoreng sampai matang. Minyak goreng bekas penggorengan tempe tersebut di atas kemudian disisihkan.

Sebanyak 0,5 liter minyak goreng digunakan untuk menggoreng tempe. Setelah tempe matang, tempe tersebut kemudian diangkat dan minyak goreng digunakan untuk menggoreng tempe kembali. Setelah itu minyak goreng disisihkan dan disimpan. Lakukan hal yang sama untuk penggorengan tempe sebanyak tiga kali. 
Ikan teri yang telah di beli dari pasar tradisional, kemudian dicuci sampai bersih dengan air. Setelah dicuci kemudian ditiriskan. Panaskan minyak 0,5 liter dalam wajan, kemudian masukkan ikan teri. Setelah dikira ikan teri cukup matang, angkat dan tiriskan. Minyak goreng bekas pemakaian untuk menggoreng ikan teri tersebut kemudian disisihkan. Lakukan hal yang sama untuk dua kali dan tiga kali penggorengan ikan teri.

Sebagai kontrol, sisihkan minyak goreng curah yang belum digunakan untuk menggoreng tempe maupun menggoreng ikan teri. Hal ini dimaksudkan sebagai pembanding untuk minyak goreng curah yang belum digunakan terhadap minyak goreng yang telah digunakan.

\section{Viskositas, Massa jenis, dan Kekeruhan}

Viskositas dapat diartikan juga sebagai suatu gesekan yang terjadi pada internal fluida. Salah satu yang dapat mempengaruhi besar viskositas adalah suhu. Pada fluida cair, nilai viskositas akan menurun pada saat suhu naik. Nilai viskositas dapat dicari dengan [7]:

$$
\begin{aligned}
& \eta=\frac{\text { Tegangan geser }}{\text { laju regangan }} \\
& \eta=\frac{F / A}{v / \iota}
\end{aligned}
$$

Dengan $\eta$ adalah viskositas, $F$ adalah gaya, A adalah luas permukaaan, $v$ laju fluida bergerak, dan $\iota$ adalah panjang pergeseran fluida bergerak.

Densitas $(\rho)$ atau massa jenis, merupakan massa $(\mathrm{m})$ persatuan volume $(\mathrm{V})$. Hal yang mempengaruhi pengukuran densitas dari suatu sampel adalah suhu dan tekanan. Secara matematis, pengukuran densitas dapat dicari dengan:

$$
\rho=\frac{m}{V}
$$

Pengukuran kekeruhan pada penelitian ini menggunakan metode Turbidimeter.

\section{HASIL DAN PEMBAHASAN}

Minyak goreng curah yang telah digunakan untuk menggoreng tempe dan ikan teri, baik minyak goreng curah kontrol, satu kali pemakaian, dua kali pemakaian dan tiga kali pemakaian, disimpan di dalam botol vial berukuran $100 \mathrm{ml}$ seperti pada Gambar 2. Pada gambar tersebut, tiga botol sebelah kiri adalah minyak goreng curah bekas pakai yang telah digunakan untuk menggoreng ikan teri. Botol di bagian paling tengah, berwarna kuning, adalah minyak goreng curah yang belum digunakan untuk menggoreng. Minyak tersebut yang akan digunakan sebagai minyak curah kontrol. Sedangkan tiga botol bagian kanan adalah minyak goreng curah yang telah digunakan untuk menggoreng tempe. Apabila diperhatikan dengan mata telanjang, bahwa warna dari minyak goreng yang telah digunakan untuk menggoreng ikan teri, mempunyai warna yang lebih gelap daripada warna dari minyak goreng yang telah digunakan untuk menggoreng tempe.

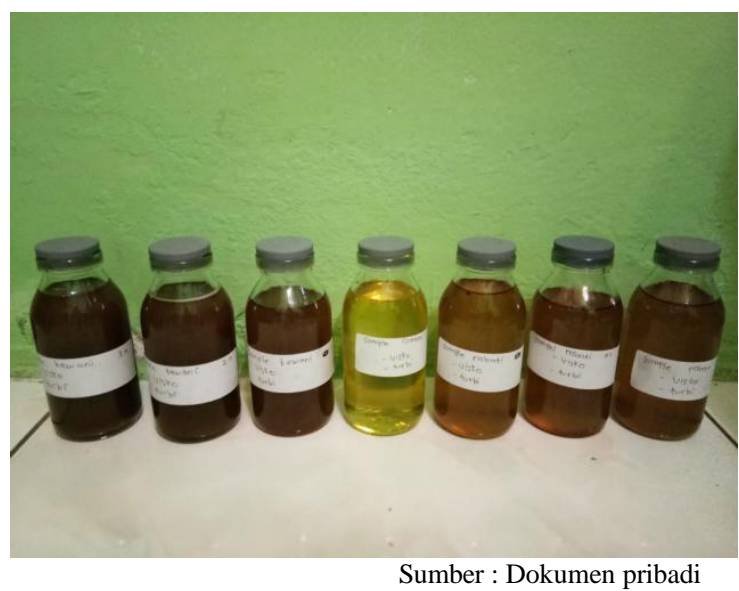

Gambar 2. Minyak goreng curah yang telah diggunakan untuk menggoreng tempe maupun ikan teri.

Minyak goreng pada Gambar 2, kemudian dibawa ke laboratorium Kimia, Departemen Kimia, Universitas Indonesia 
untuk dilakukan analisis dan pengujian. Pengujian yang akan dilakukan antara lain adalah massa jenis, kekeruhan, dan viskositas.

\section{Massa Jenis Minyak Goreng Curah Bekas Pakai}

Besar dari analisis massa jenis terhadap minyak curah habis pakai seperti ditunjukkan Tabel 1 dan Gambar 3. Nilai massa jenis kontrol dari minyak curah yang belum digunakan sebesar $0,91 \mathrm{~g} / \mathrm{ml}$. berdasarkan tabel dan gambar hasil pengukuran, diketahui bahwa untuk minyak goreng bekas pemakaian ikan teri, diperoleh nilai yang stabil dengan nilai $0,91 \mathrm{~g} / \mathrm{ml}$.

Tabel 1. Besar Nilai Massa Jenis Minyak Bekas Pemakaian Ikan Teri dan Tempe

\begin{tabular}{|c|c|c|c|c|c|}
\hline \multicolumn{6}{|c|}{ Massa Jenis } \\
\hline No & Sampel & $\mathbf{0 x}$ & $1 \mathbf{x}$ & $2 x$ & $3 \mathbf{x}$ \\
\hline 1 & Ikan Teri & 0.91 & 0.91 & 0.91 & 0.91 \\
\hline 2 & Tempe & 0.91 & 0.90 & 0.91 & 0.91 \\
\hline
\end{tabular}

Sedangkan minyak goreng curah yang telah digunakan untuk menggoreng tempe, diperoleh hasil bahwa nilai massa jenis minyak yang telah digunakan untuk sekali penggorengan diperoleh nilai yang lebih rendah daripada minyak curah kontrolnya, yaitu $0,90 \mathrm{~g} / \mathrm{ml}$. Selanjutnya, pada penggorengan kedua dan ketiga diperoleh kenaikan massa jenis menjadi $0,91 \mathrm{~g} / \mathrm{ml}$.

Penelitian yang dilakukan [6] menyatakan bahwa massa jenis minyak yang paling besar adalah massa jenis minyak yang belum digunakan atau belum mengalami pemanasan. Hal ini dikarenakan minyak tersebut masih memiliki molekul-molekul yang belum merenggang yang diakibatkan oleh pemanasan, serta masih memiliki kerapatan yang besar. Minyak goreng yang sudah dipanaskan, memiliki ikatan molekul yang berkurang dan menyebabkan kerapatan juga berkurang.

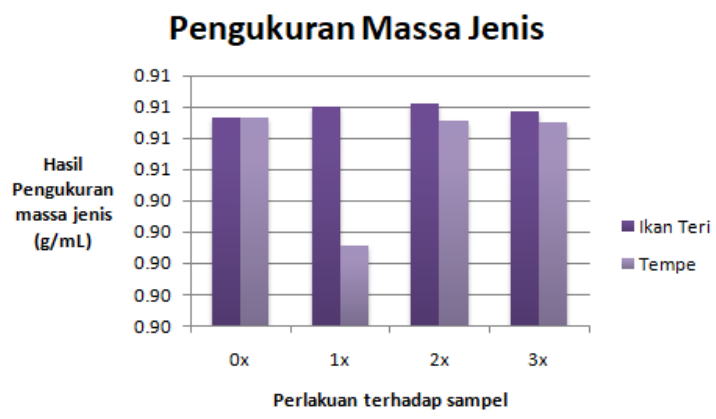

Sumber : Dokumen pribadi

Gambar 3. Massa jenis minyak curah habis pakai

\section{Nilai kekeruhan minyak goreng curah bekas pakai}

Besar nilai kekeruhan minyak goreng bekas pakai, seperti ditunjukkan pada Tabel 2 dan Gambar 4. Besar nilai kontrol untuk tingkat kekeruhan minyak goreng curah adalah 12,85 NTU (Nephelometric Turbidity Unit). Besar nilai kekeruhan untuk minyak goreng curah bekas pemakaian untuk ikan teri menunjukkan nilai yang semakin meningkat untuk pemakaian satu kali dan dua kali pemakaian. Tetapi, nilai kekeruhan menurun pada penggorengan minyak curah yang ketiga.

Sedangkan nilai kekeruhan pada minyak goreng curah yang telah digunakan untuk menggoreng tempe diperoleh nilai yang lebih rendah dari nilai kontrolnya. Penggorengan minyak yang pertama diperoleh nilai kekeruhan 4,99 NTU. Jauh lebih rendah daripada nilai kontrolnya. Minyak goreng curah yang telah digunakan dua kali penggorengan mengalami kenaikan daripada nilai kekeruhan satu kali penggorengan. Hampir dua kali nilainya dari yang pertama. Tetapi pada proses penggorengan yang ketiga, nilai kekeruhannya kembali menurun.

Minyak goreng yang sudah sering diulang terus menerus dalam penggunaannya akan mengalami penurunan standar mutu [3]. Standar mutu tersebut ditandai dengan bau tengik dan warna yang cenderung gelap, 
yang dapat berpotensi membahayakan tubuh.

Tabel 2. Besar Nilai Kekeruhan Minyak Bekas Pemakaian Ikan Teri dan Tempe

\begin{tabular}{rlrrrr}
\hline \multicolumn{6}{c}{ Kekeruhan } \\
\hline No & Sampel & \multicolumn{1}{l}{ 0x } & \multicolumn{1}{c}{$\mathbf{1 x}$} & \multicolumn{1}{c}{$\mathbf{2 x}$} & \multicolumn{1}{c}{ 3x } \\
\hline 1 & Ikan Teri & 12.85 & 21.65 & 34.25 & 28.55 \\
2 & Tempe & 12.85 & 4.99 & 8.19 & 5.78 \\
\hline \multicolumn{5}{c}{ Sumber :Dokumen pribadi }
\end{tabular}

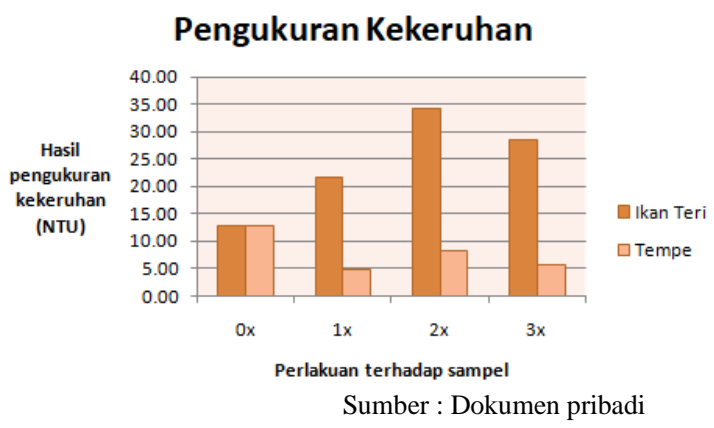

Gambar 4. Tingkat kekeruhan minyak curah habis pakai

Dari hasil tersebut di atas sehingga dapat disimpulkan bahwa baik minyak goreng yang telah digunakan untuk menggoreng ikan teri maupun tempe, pada penggorengan ketiga mengalami penurunan nilai kekeruhan.

\section{Viskositas Minyak Goreng Curah Bekas Pakai}

Besar nilai viskositas minyak goreng curah bekas pakai diperlihatkan seperti pada Tabel 3 dan Gambar 5. Nilai kontrol untuk nilai viskositas adalah $67 \mathrm{mPa}$.s. Besar nilai viskositas untuk minyak goreng curah yang telah digunakan untuk menggoreng ikan teri, diperoleh hasil bahwa terjadi kenaikan nilai pada satu kali penggorengan jika dibandingkan dengan nilai kontrolnya. Tetapi, setelah digunakan untuk dua kali penggorengan terjadi penurunan nilai viskositas. Nilai tersebut masih sama dengan nilai kontrolnya. Kemudian setelah digunakan tiga kali penggorengan, diperoleh nilai viskositas yang naik kembali.

Sedangkan untuk minyak goreng curah yang telah digunakan untuk menggoreng tempe, diperoleh nilai yang drastis menurun pada penggorengan pertama jika dibandingkan dengan nilai kontrolnya. Tetapi, pada bekas penggorengan yang kedua diperoleh nilai yang naik dan tinggi yaitu $70 \mathrm{mPa} . \mathrm{s}$, sedangkan setelah proses penggorengan yang ketiga diperoleh nilai yang kembali menurun.

Tabel 3. Besar nilai viskositas minyak bekas pemakaian ikan teri dan tempe

\begin{tabular}{clcccc}
\hline \multicolumn{5}{c}{ Viskositas } \\
\hline No & Sampel & 0x & $\mathbf{1} \mathbf{x}$ & $\mathbf{2 x}$ & $\mathbf{3 x}$ \\
\hline 1 & Ikan Teri & 67.00 & 70.00 & 67.00 & 70.00 \\
2 & Tempe & 67.00 & 55.30 & 70.00 & 67.00 \\
\hline \multicolumn{5}{c}{ Sumber :Dokumen pribadi }
\end{tabular}

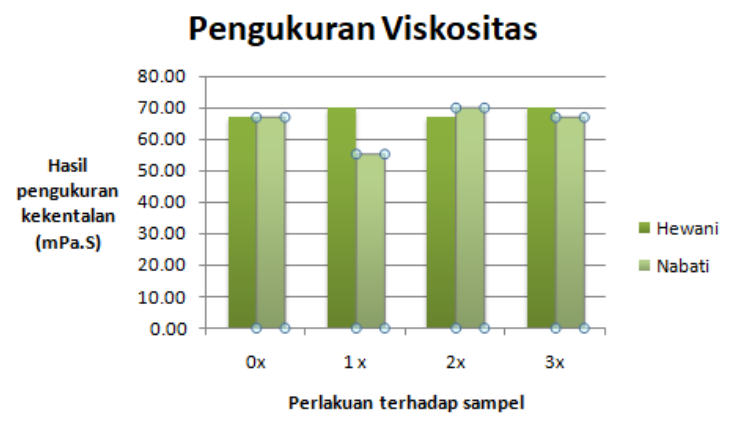

Gambar 5. Nilai viskositas minyak curah habis pakai

Pola naik turun pada hasil viskositas dari minyak goreng bekas pemakaian tempe ini, sangat berkebalikan jika dibandingkan dengan hasil dari viskositas untuk minyak goreng bekas pemakaian ikan teri. Saat nilai viskositas pada bekas pemakaian ikan teri naik, nilai viskositas minyak goreng bekas pemakaian tempe menurun seperti ditunjukkan pada setelah pemakaian satu kali dan tiga kali. Selain itu, saat nilai viskositas dari minyak goreng bekas pemakaian untuk menggoreng ikan teri turun, nilai dari viskositas bekas pemakaian tempe naik. 
Referensi [5] pernah melakukan penelitian tentang uji viskositas terhadap minyak goreng. Dalam penelitiannya diketahui bahwa nilai viskositas terbesar terdapat pada minyak goreng yang belum pernah dipakai, sedangkan nilai terkecil terdapat pada minyak goreng yang telah digunakan dua kali penggorengan. Hasil tersebut, berbeda dengan hasil penelitian yang telah dilakukan. Nilai dari viskositas tebesar pada minyak goreng bekas pakai untuk ikan teri terdapat pada penggorengan pertama dan ketiga. Hasil dari penggorengan kedua cenderung menurun dan sama besar dengan nilai dari minyak goreng yang belum pernah digunakan untuk menggoreng. Sedangkan pada minyak goreng bekas penggorengan tempe nilai viskositas terbesar terdapat pada dua kali proses penggorengan, sedangkan nilai terendah pada satu kali penggorengan.

\section{SIMPULAN}

Berdasarkan penelitian yang telah dilakukan, dapat disimpulkan bahwa :

1. Terjadi perbedaan nilai pengukuran secara kuantitas pada parameter kekeruhan dan viskositas. Sedangkan pada pengukuran massa jenis, memiliki nilai yang hampir sama, hanya berbeda pada minyak goreng $1 \mathrm{x}$ penggorengan.

2. Pengukuran nilai kekeruhan pada minyak goreng bekas pemakaian ikan teri mempunyai nilai yang lebih tinggi daripada kontrolnya, berkebalikan dengan minyak goreng bekas pemakaian tempe yang nilainya cenderung lebih rendah dari nilai kontrolnya.

3. Diagram hasil pengukuran nilai viskositas baik minyak goreng bekas pemakaian ikan teri maupun tempe, mempunyai nilai yang berkebalikan.

\section{UCAPAN TERIMAKASIH}

Ucapan terimakasih ditujukan kepada Universitas Indraprasta PGRI Jakarta melalui LPPM Universitas Indraprasta PGRI atas dana hibah penelitian DIPA
Unindra sesuai kontrak penelitian Nomor 1289/SP3/KP/LPPM/UNINDRA/IX/2018.

\section{DAFTAR PUSTAKA}

[1] Aminah, siti. 2010. Bilangan peroksida minyak goreng curah dan sifat organoleptik tempe pada pengulangan penggorengan. Jurnal Pangan dan Gizi Vol 01 No 01.

[2] Aminah, S., dan Isworo, J. T. 2010. Praktek penggorengan dan mutu minyak goreng sisa pada rumah tangga di RT V RW III Kedungmundu Tembalang Semarang. Prosiding Seminar Nasional Unimus hal. 261-267.

[3] Aziz, T., Shabrina, D., \& Novia Pratiwi, Rinny. 2016. Penurunan Kadar FFA dan Warna Minyak Jelantah Menggunakan Absorben dari Biji Kurma dan Kulit Salak. Jurnal Teknik Kimia Vol. 22 No. 1.

[4] Martianto, D., Marliyati, S. A., dan Arafah, A. A. 2009. Retensi vitamin A pada minyak goreng curah yang difortifikasi vitamin A dan produk gorengannya. $J$. Teknol. dan Industri Pangan Vol XX No. 2.

[5] Sutiah, S., Firdausi, K. S., \& Budi, W. S. (2008). Studi kualitas minyak goreng dengan parameter viskositas dan indeks bias. Berkala Fisika, 11(2), 53-58.

[6] Warsito, Ahmad Pauzi, G., \& Jannah, Miftahul. 2013. Analisis Pengaruh Massa Jenis Terhadap Kualitas Minyak Goreng Kelapa Sawit Menggunakan Alat Ukur Massa Jenis dan Akuisisinya pada Komputer. Prosiding Semirata FMIPA Universitas Lampung.

[7] Young, Hugh D., \& Freedman, Roger A. 2002. Fisika Universitas. Jakarta : Erlangga. 